\title{
Sub-Saharan Africa's engagement with emerging partners: opportunities and challenges
}

\author{
Samah S. A. Elmorsy ${ }^{*}$
}

\author{
*Correspondence: \\ salamlm3@yahoo.com \\ Department of Politics \\ and Economics, Institute \\ of African Research \\ and Studies, Cairo University, \\ Giza, Egypt
}

\begin{abstract}
The aim of the paper is to analyze the economic impact of Sub-Saharan Africa's (SSA) engagement with emerging partners (China, India and Brazil BICs) and to determine the opportunities and challenges of the increasingly engaging with the new partners. In order to achieve the aim of the paper it estimated the most effective variables that determine the trade intensity between SSA and Chinausing Gravity model approach. The paper concluded that the most important variables that have the major effect on the value of exports of Sub-Saharan Africa to Chinawere rate of mobile telephone in China (infrastructure variable) and China FDI to Sub-Saharan Africa because much of China's outward direct investment (ODI) in SSA is closely linked to trade. Africa's exports to the BICs are dominated by fuels and primary commodities (mainly to China and India); the BIC's exports to African countries are dominated by manufactured goods. Chinese FDI can be categorized as resource-efficiency — and market-seeking investments.
\end{abstract}

Keywords: Sub-Saharan Africa, BICs, Trade, FDI, Official Development Assistance, South-South cooperation

\section{Background}

Africa has a history of cooperation with the South. Its formal involvement in SouthSouth cooperation dates back to 1955 when African and Asian nations, most of them newly independent, held a conference in Bandung, Indonesia, to promote economic and cultural cooperation and bring an end to colonialism. The Bandung Conference called for the promotion of world peace and underscored the need for developing nations to reduce their dependence on industrialized countries by providing technical assistance to one another. Furthermore, the Bandung Conference provided inspiration and impetus for the development of various South-South alliances in the 1960s and 1970s. For example, it led to the creation of the Non-Aligned Movement in 1961. It also provided impetus for the creation of the Group of 77 (G-77) during the first United Nations Conference on Trade and Development (UNCTAD) in 1964. The G-77 has established itself as the leading voice of the South in the global arena. It has also played a lead role in establishing a conceptual framework and guiding principles for South-South cooperation. 
After a long history of reliance on trade with and investment from Europe and North America, Sub-Saharan African countries are increasingly engaging with other partners, during the past decade, Sub-Saharan African countries have increasingly started exploiting new markets, marking what seems to be a historic reorientation of their trade and investment toward new partners.

Emerging partners are now a major source and destination of trade with and investment in Sub-Saharan African countries, and this trend is most likely to accelerate in the coming years. Sub-Saharan Africa's exports with non-traditional partners accounting for about $50 \%$ of its total exports and almost $60 \%$ of its total imports during 2010. This reorientation is driven mostly by the large economies of Brazil, India, and China (BICs). A similar reorientation is also taking place in investment flows, with China accounting for $16 \%$ of total foreign direct investment (FDI) flows to the region; other emerging countries are also making considerable investments in Sub-Saharan Africa.

The aim of the paper is to analyze the economic impact of Sub-Saharan Africa's engagement with emerging partners throw analyzing the following main Pillars:

I. Theoretical issues: International Cooperation Theory

II. Africa-South cooperation: background

III. The methodology

IV. Reorientation on Sub-Saharan African countries toward new markets

V. Opportunities, challenges and policy implications

Conclusion

\section{Theoretical issues: International Cooperation Theory}

The role of BICs in Africa is best analyzed through the optics of international cooperation theory for Africa's trade with, and investment and aid from the BICs.

\section{The role of trade}

The economic literature postulates that an internationally integrated economy offers a substantial increase in demand and simultaneously more potential for economies of scale than a closed economy. Many studies conclude that trade has a positive effect on economic growth.

Trade also helps economies to specialize, increase their resource productivity, raise aggregate output, create jobs, generate income and relax foreign exchange restraints. Export-led approaches and export promotion lead to high growth, returns to entrepreneurial effort increase with exposure to foreign competition.

Trade transmits economic growth through three main channels: economies of scale, efficiency gains and the technology cycle. Economies of scale are directly related to the monopoly profits in production for niche markets. Efficiency gains are linked to reducedcost effects through foreign competition that eventually become evident in a falling rate of inflation in the domestic economy. Finally, the technology cycle refers to the growth effects that derive from the profitable adoption and application of foreign technologies in domestic production processes [Economic Commission for Africa (ECA) 2013:6-7].

Yet Africa must take into account several risks in its trade cooperation with the BICs. First, trade-led growth of national output may have little impact on employment and development, particularly when most of the trade is in primary commodities with few 
linkages to the rest of the economy and when many export earnings accrue to foreigners, which not only bias the economy in the wrong direction but also reinforce internal and external dualities and inequalities. Second, the growth of China and other BICs suggests that Africa may find it harder to break into exporting in non-primary commodity sectors as well. However, with wages rising in China-often steeply-new opportunities may emerge for African countries (Uma Subramanian and Matthias Matthijs 2007:5).

\section{The role of foreign direct investment}

The development literature encompasses several positions on the degree to which FDI affects economic growth. One view is that it may affect it directly because it contributes to capital accumulation, and the transfer of new technologies to the recipient country. Others contend that FDI enhances economic growth indirectly where the direct transfer of technology augments the stock of knowledge in the recipient country through labour training and skill acquisition, new management practices and organizational arrangements. FDI thus enhances employment in the recipient country via the newly acquired skills as well as the management and organizational arrangements often referred to as "entrepreneurship" for the host country population [United Nations Conference on Trade and Development (UNCTAD) 2005a, b:37].

The effects of FDI on economic growth in the host country differ by growth modelneoclassical or endogenous. With the former, FDI can only affect growth in the short run because in the long run, diminishing returns to capital set in. It also postulates that longrun growth can only arise from both exogenous labour force growth and technological progress. Endogenous growth models, in contrast argue that FDI promotes economic growth even in the long run through permanent knowledge transfer, as via technology spillovers from advanced to lagging countries (Qimiao Fan et al. 2007:74).

\section{The role of development assistance}

The theoretical and empirical literature does not reveal an automatic, beneficial impact of development assistance on a recipient country: the mode and type of aid as well as the country's socio-economic and political environment are important in enhancing its growth impact.

Studies on aid's impact on growth and development follow four main strands of thinking. One group of studies argues that aid has either no effect on growth or even undermines it. Generally, they share a view that aid is counterproductive in that it generates a low-growth economy where aid dependency expands public spending and wipes out domestic savings (Ali Zafar 2007:106-108).

A second set of studies finds an average significant positive impact of aid on growth. This set argues that those contending that aid does not enhance growth have only a partial argument, in that aid has supported poverty reduction and growth promotion in many countries-thus even if aid has not stimulated growth in all circumstances, on average it has had a positive effect.

A third group of studies argued that aid has a positive relationship with growth only in certain conditions, including the characteristics of both recipient and donor practices, while the average effect of aid is close to zero. 
The fourth set attempted to match aid flows to realistic period over which they could influence growth (EAC 2013:8-9).

\section{Africa-South cooperation: background}

Africa's cooperation with the South is generally of three types. The first form of cooperation arrangement is bilateral, between African countries and a developing country in another region. For example, it includes, among others, bilateral partnerships between Africa and developing countries such as China, India, the Republic of Korea and Turkey. The second form of cooperation is trilateral in the sense that it is between an African country and two developing countries in different regions. The main cooperation framework in this category is the India-Brazil-South Africa (IBSA) partnership. The third form of cooperation is at the regional level between Africa and other developing country regions. The three main cooperation arrangements in this category are the New AsianAfrican Strategic Partnership, the Africa-South America Initiative and the Afro-Arab Cooperation Initiative (UNCTAD 2010:11) (Fig. 1).

\section{China-Africa partnership}

It should be noted that China's engagement with Africa has evolved over the years, Since the 1990s; there have been renewed efforts to strengthen cooperation with the region. This began with a visit to the region by Chinese President Jiang Zemin in 1996 where he unveiled plans to create the Forum on China-Africa Cooperation (FOCAC) (UNCTAD 2008:7-9).

The launching of FOCAC in Beijing in 2000 ushered in a new era of relations between China and Africa, driven mostly by commercial and economic interests rather than political ideology as in the past. The new relationship is also marked by the intensification of high-level visits to Africa by Chinese officials as well as an increase in trade, finance and investment. The broad priority areas of cooperation identified by China and African countries include: political affairs; international affairs, economic and development issues; peace and security; and cultural and people-to-people exchanges.

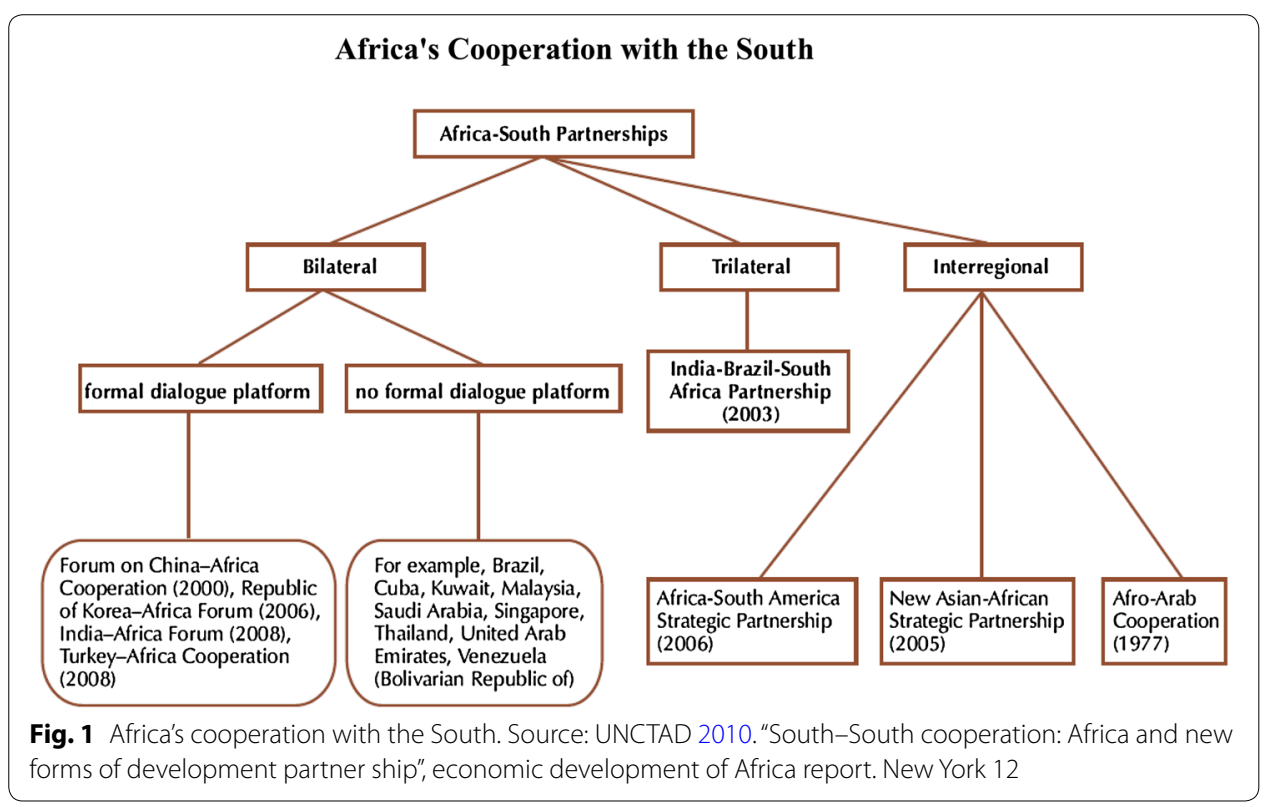


FOCAC has become the platform for coordination of China-Africa relations and for dialogue between African countries and China. The meetings are held every 3 years mostly at the ministerial level, although they are often attended by heads of state and government (Viven Foster et al. 2008:1).

There are several interesting and novel features of China's engagement with Africa that are worth emphasizing. First, is that it uses FOCAC as a platform for making pledges and commitments to the region. These are usually multi-year commitments and their forward-looking nature makes Chinese financial support increasingly predictable. Second, FOCAC meetings are used to monitor progress in the implementation of existing commitments to Africa. This inbuilt monitoring mechanism increases the likelihood that commitments will be fulfilled and has become a model for other Southern partners. Third, China has made addressing climate change an important area of its support to the region. Fourth, China is increasingly making efforts to integrate the private sector into its Africa relations, although the latter is still a passive participant in the FOCAC process.

China's growing engagement in Africa has generated interest and debate on its contribution to economic and social development in the region. In general, the new partnership with Africa has led to closer political and cultural ties between China and Africa. Both sides have had frequent exchanges of high-level visits in recent years and provide support for each other in multilateral affairs. China has also made contributions to maintenance of peace and security in the region. Trade and finance are two key areas where China's engagement has had very significant impact in the region. China has also contributed to economic development in the region through the provision of concessional loans and grants, support for infrastructure, generous debt relief, the opening up of its market to Africa goods and support for human resource development and medical care (UNCTAD 2010:11-16).

\section{India-Africa partnership}

India has also had close relations with African countries since their independence in the 1960s. Until recently, India's relations with Africa focused more on the provision of technical assistance and capacity-building and there was no formal dialogue platform for cooperation with the region. In 2008, the Indian Government decided to create a new architecture for its engagement with Africa and this led to the convening of the First India-Africa Forum Summit in New Delhi from 8-9 April 2008. At the summit, India and Africa agreed to enhance cooperation in the following broad areas: economics; politics; science, research and technology; social development and capacity-building; tourism; infrastructure, energy and environment; and media and communication. The summit is held every 3 years at the level of heads of state and government.

India's cooperation with Africa has had positive impact in Africa. There hasbeen a significant increase in the volume of trade and investment flows between India and Africa. India has also contributed to Africa's development through loans, debt relief, technical assistance, peacekeeping and infrastructure finance (UNCTAD 2005a, b:31).

\section{Brazil-Africa partnerships}

Brazil has bilateral cooperation arrangements with individual countries in the region for which there is no formal bilateral dialogue platform, and has provided support to them through projects in areas such as health, infrastructure and agriculture. Brazil is also key 
driver of interregional cooperation partnerships between South America and Africa. Furthermore, it is active promoters of cooperation among developing countries in multilateral negotiations and reform of the international financial architecture.

Brazil has a unique partnership arrangement with India and South Africa that has attracted international attention. The IBSA partnership is a trilateral alliance between Brazil, India and South Africa aimed at boosting their bargaining power and clout on global issues and strengthening economic and political ties amongst the three countries. Since its inception in 2003, it has become a powerful force in setting the agenda and pace of multilateral negotiations. It also plays an important role in ensuring that the concerns and interests of developing countries are taken into account in global responses to the financial crisis and the reform of the international financial architecture (UNCTAD 2010:16-20).

\section{Methods}

\section{Estimation determinates of Sub-Saharan Africa's trade intensity with China}

1-Brief overview of the gravity model methodology

The gravity model has been widely used to identify determinants of bilateral trade, though it is often criticized for lacking a strong theoretical basis. Despite its use in many early studies of international trade, the model was considered suspect in that it could not easily be shown to be consistent with the dominant Heckscher-Ohlin model explaining net trade flows in terms of differential factor endowments. In a typical gravity model, bilateral trade flows are determined by the size of the two economies and the distance between them. However, it is always possible to expand the model to include other relevant determinants of trade. The following standard gravity model is specified and estimated to examine the potential for Sub-Saharan African's trade with China:

$$
\begin{aligned}
T_{i j}= & \beta_{0}+\beta_{1}\left(Y_{i} Y_{j}\right)+\beta_{2}\left[\left(Y C_{i} Y C_{j}\right)\right]+\beta_{3} \text { Dist }_{i j}+\beta_{4}\left(\text { Area }_{i} \text { Area }_{j}\right) \\
& +\beta_{5}\left|Y C_{i}-Y C_{j}\right|+\left[\beta_{i} \sum Z_{i}+\beta_{j} \sum Z_{j}\right]
\end{aligned}
$$

where $\mathrm{T}$ is bilateral trade between country $\mathrm{i}$ and $\mathrm{j} ; \mathrm{Y}$ is GDP; $\mathrm{YC}$ is GDP per capita and $\mathrm{Z}_{\mathrm{i}}$ and $Z_{j}$ are other relevant variables grouped under "infrastructure" (paved road length as per cent of total, number of mobile telephone per 1000 people), policy (FDI in reporting countries, tax on international trade in partner country), "cultural and geographic" distance between the capitals of the trading countries, common official language, sharing border, being landlocked) and membership in regional groupings.

Expected signs: $\beta_{1}$ and $\beta_{2}$ are expected to be positive; $\beta_{3}, \beta_{4}$ and $\beta_{5}$ are expected to be negative. Infrastructure variables, sharing border and common official language, membership to a particular REC as well as FDI are expected to be positive, while being landlocked is expected to be negative (EAC 2010, 392).

According to gravity model, paper designed the following equation to estimate determinates of SSA's trade Intensity with China.

$$
Y_{i j}=f\left(X_{1}, X_{2}, X_{3}, X_{4}, X_{5}, X_{6}, X_{7}, X_{8}, X_{9}\right)
$$

where:

$\mathrm{Y}_{\mathrm{ij}}=$ bilateral trade between SSA and China (value of exports from SSA to China during 2000-2013 in Billion dollars) 
$\mathrm{X}_{1}=$ China Gross Domestic Product (GDP) during 2000-2013, in real constant price 2000 (100 million Yuan).

$\mathrm{X}_{2}=$ per capita indices of China Gross Demotic Product (during 2000-2013)

$\mathrm{X}_{3}=$ China population (during 2000-2013, 10,000 person)

$\mathrm{X}_{4}=$ length of High ways in China (during 2000-2013, 10,000 km)

$\mathrm{X}_{5}=$ rate of mobile telephone in China (during 2000-2013 sets/100 persons).

$\mathrm{X}_{6}=$ dummy variable about political stability in China, takes one where is apolitical stability and takes zero where is apolitical instability(during 2000-2013)

$\mathrm{X}_{7}=$ China FDI to Sub-Saharan Africa (during 2000-2013 in million dollars)

$\mathrm{X}_{8}=$ China average Applied Import MFN Tariff Rates on non-Agricultural and nonfuel (during 2000-2013)

X9 = dummy variable takes Value of 1 if there is bilateral trade agreements between China and Sub-Saharan Africa and takes 0 if there isn't

\section{2-Source of data}

Paper collected time series data about variables defined in the model, data collected covered 14 year (2000-2013) from the following reports:

- UNCTAD hand book of statistics.

- China statistical year book.

- Statistical bulletin of China.

\section{3-Model results and discussion}

Detailed results of the model are shown in statistical Appendix; paper concluded that the most effective variables that have the major effect on the value of exports of SubSaharan Africa to China were $\left(\mathrm{X}_{5}\right)$ rate of mobile telephone in China (infrastructure variable) and (X7) China FDI to Sub-Saharan Africa because much of China's outward direct investment (ODI) in SSA is closely linked to trade.

\section{Reorientation on Sub-Saharan African countries toward new markets}

After a long history of reliance on trade with and investment from Europe and North America, Sub-Saharan African countries are increasingly engaging with other partners, including those in their region. This is not unexpected, as emerging markets have maintained significantly faster economic growth than advanced economics over the last few decades. It is also consistent with the higher natural resource intensity in emerging partners compared with advanced economies and Sub-Saharan Africa's natural resources abundance. As this section describes, emerging partners are now a major source and destination of trade with and investment in Sub-Saharan African countries, and this trend is most likely to accelerate in the coming years (Harry G. Broadman 2007:84).

\section{1-Trade}

During the past decade, with unprecedented high growth in their exports and imports, Sub-Saharan African countries have begun engaging with emerging economies in other regions and with other countries within Sub-Saharan Africa. 
This trade reorientation toward new partners is taking place relatively fast, driven by increasing trade with a few large emerging markets economics and by intraregional trade, in a way that is largely homogenous across the region. Specifically, this trade reorientation is:

- Fast-paced. Between 1990 and 2010, the share of Sub-Saharan Africa's exports to advanced economics declined from 78 to $52 \%$, and the share of Sub-Saharan Africa's imports from those countries declined from 73 to $43 \%$. Most of this reorientation has occurred during the past 15 years, as the share of both Sub-Saharan Africa's exports to and imports from member countries of the Organization for Economic Cooperation and Development's Development Assistance Committee (DAC) declined from about $70 \%$ in 2000 to approximately $50 \%$ in 2010. The magnitude of the reorientation in Sub-Saharan Africa's trade was not determined solely by oil-related trade, as non-oil-exporting Sub-Saharan Africa countries also saw the share of DAC countries in their total trade decline by an amount of the same magnitude.

- Driven mostly by the large emerging economies of Brazil, India and China. By 2010, the share of Sub-Saharan Africa trade with Brazil, India, and China reached approximately 3, 6 and $17 \%$, respectively, rising from negligible shares in the 1990s [International Monetary Fund (IMF) 2011:40-41] (Fig. 2).

All Sub-Saharan African subgroups (oil exporters, low-income countries, middleincome countries) are exporting a lower share of their products to traditional DAC partners than they were in 1990 and all are now exporting more to China. Except for oil-exporting countries, all sub-groups have also seen an increase in their share of trade to other Sub-Saharan African countries. On the other hand, the reorientation toward Brazil and India appears more heterogeneous across subgroups. In regard to imports, all subgroups of Sub-Saharan African countries have seen a considerable reduction in their imports from traditional DAC partners, and all are increasingly relying on Chinese and intraregional imports (IMF 2011:42-43) (Fig. 3).

\section{Sectoral Composition of the Reorientation}

\section{Exports}

Sub-Saharan Africa exports to BICs are heavily concentrated in primary products, mainly oil. By 2008, oil accounted for about 70 \% of all Sub-Saharan Africa exports to BICs and for more than $80 \%$ of exports if South African exports are excluded. Note that Sub-Saharan Africa exports to BICs are more concentrated in oil and gas than exports to DAC countries, as Sub-Saharan African countries tend to export more food, beverages, and manufactured goods to DAC countries than to BICs (IMF 2011:45) (Fig. 4).

\section{Imports}

They are largely machinery, chemicals, and manufactured goods, although there is some heterogeneity across trading partners. Sub-Saharan African imports from BICs are actually more concentrated in manufactured products-especially from China-than is the case with imports from DAC countries, the latter being more focused on imports of machinery. Imports from India are more concentrated in machinery and fuel (refined oil), and imports from Brazil are most concentrated in food and live animals. Imports from the Group of Five are quite diverse, with significant shares for food and live 


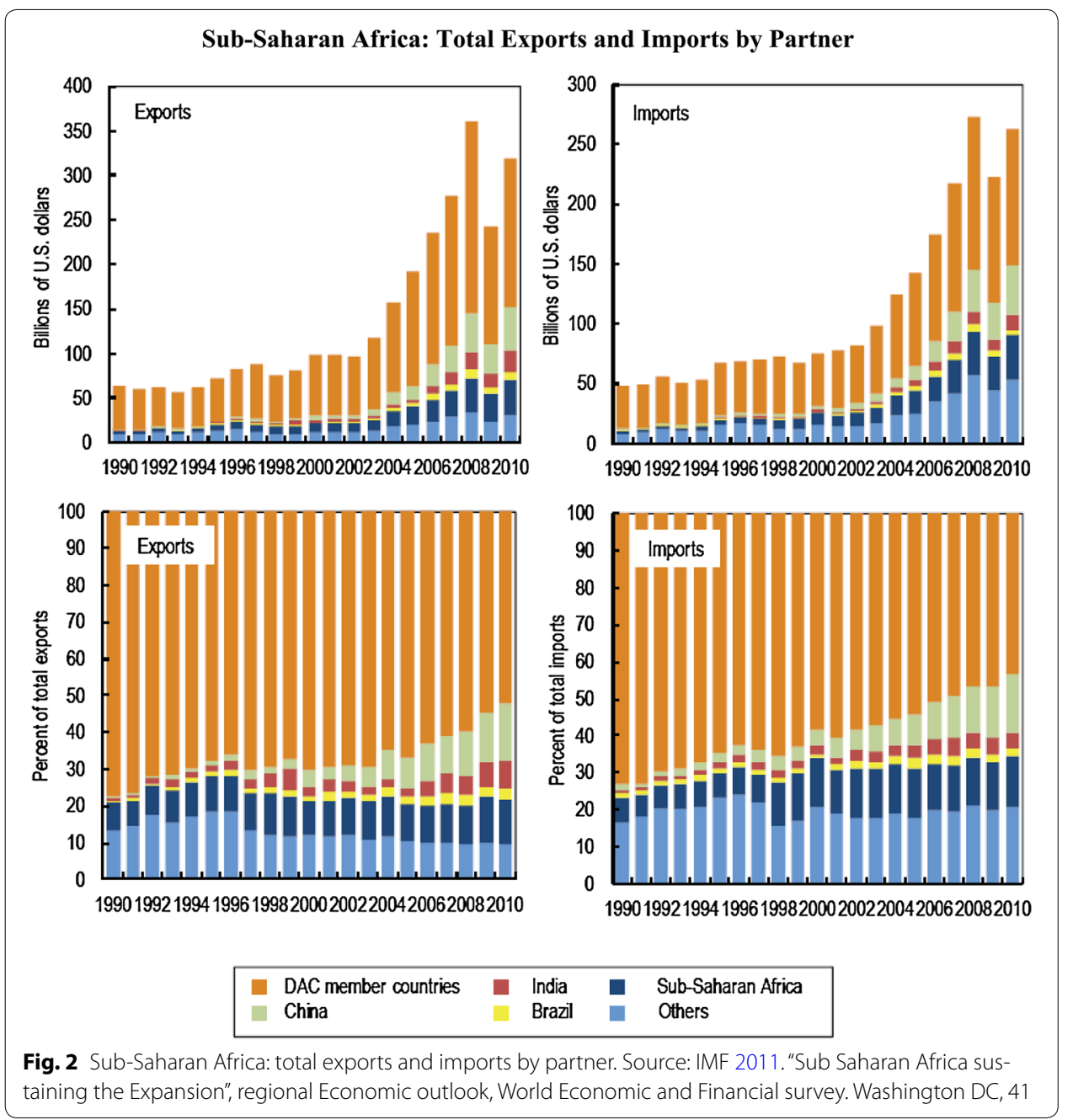

animals, animal and vegetable oils, manufactured goods, and machinery (IMF 2011:46) (Fig. 5).

\section{2-Foreign Direct Investment (FDI)}

A similar reorientation is occurring in Sub-Saharan Africa's sources of capital, as emerging countries such as the BICs, have rapidly increased their investments in the region. Chinese FDI to Sub-Saharan Africa, as a share of total FDI to the region, climbed from less than $1 \%$ in 2003 to $16 \%$ by 2008 . Investment from India is also significant: by 2006 , Indian investment stocks in Sub-Saharan Africa were almost as large as Chinese FDI flows in the region (Viven Foster 2009:4).

Much of China's outward direct investment (ODI) in SSA is closely linked to trade. Official figures from the Chinese Ministry of Commerce suggest that in 2012 ODI to SSA reached US $\$ 2.52$ billion, up from .39 US\$ billion in 2005. In 2012 the total stock of Chinese ODI was US $\$ 20$ billion (Fig. 6).

Although most of the emerging partners' investments are in mining, investments in other sectors are also significant. Besides oil and mining, Chinese investment is also 


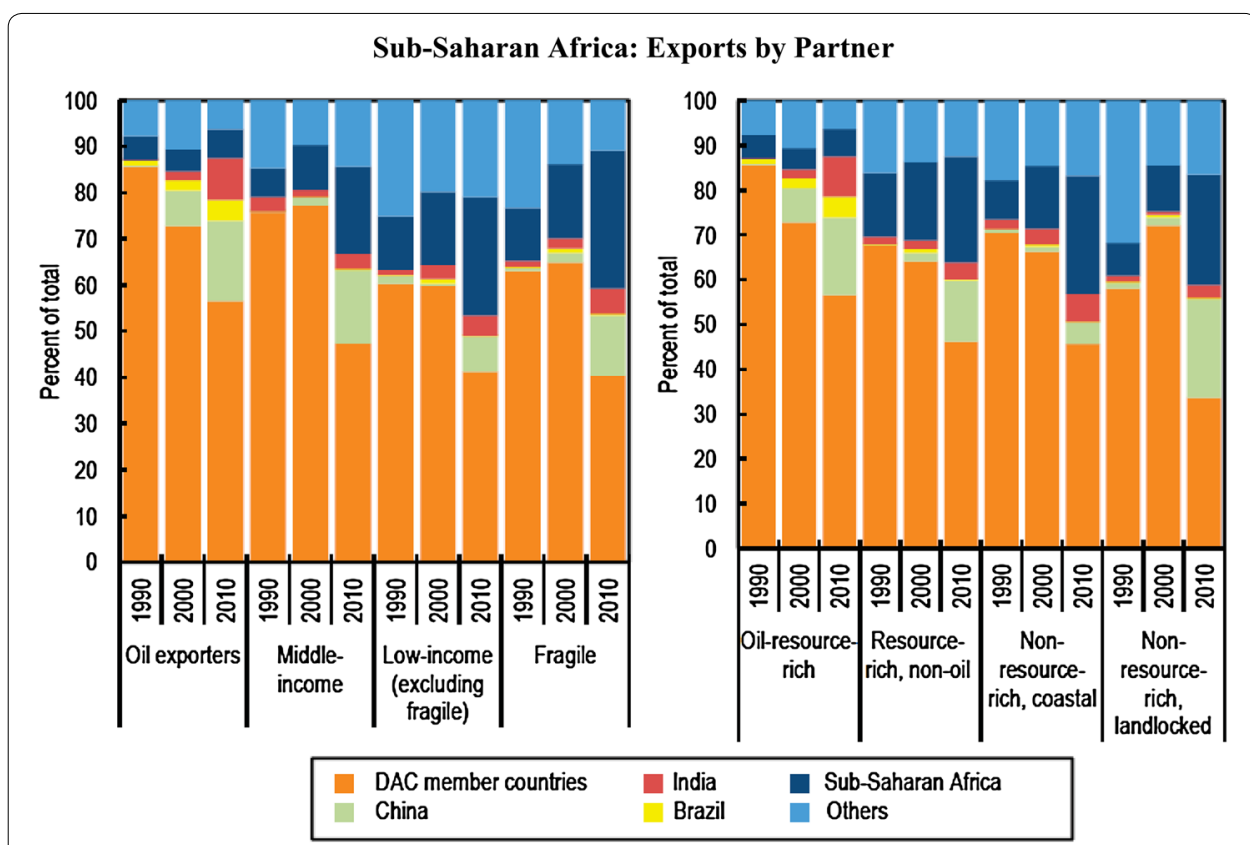

Fig. 3 Sub-Saharan Africa: exports by partner. Source: IMF 2011. "Sub Saharan Africa sustaining the expansion", regional economic outlook, world economic and financial survey. Washington DC, 43

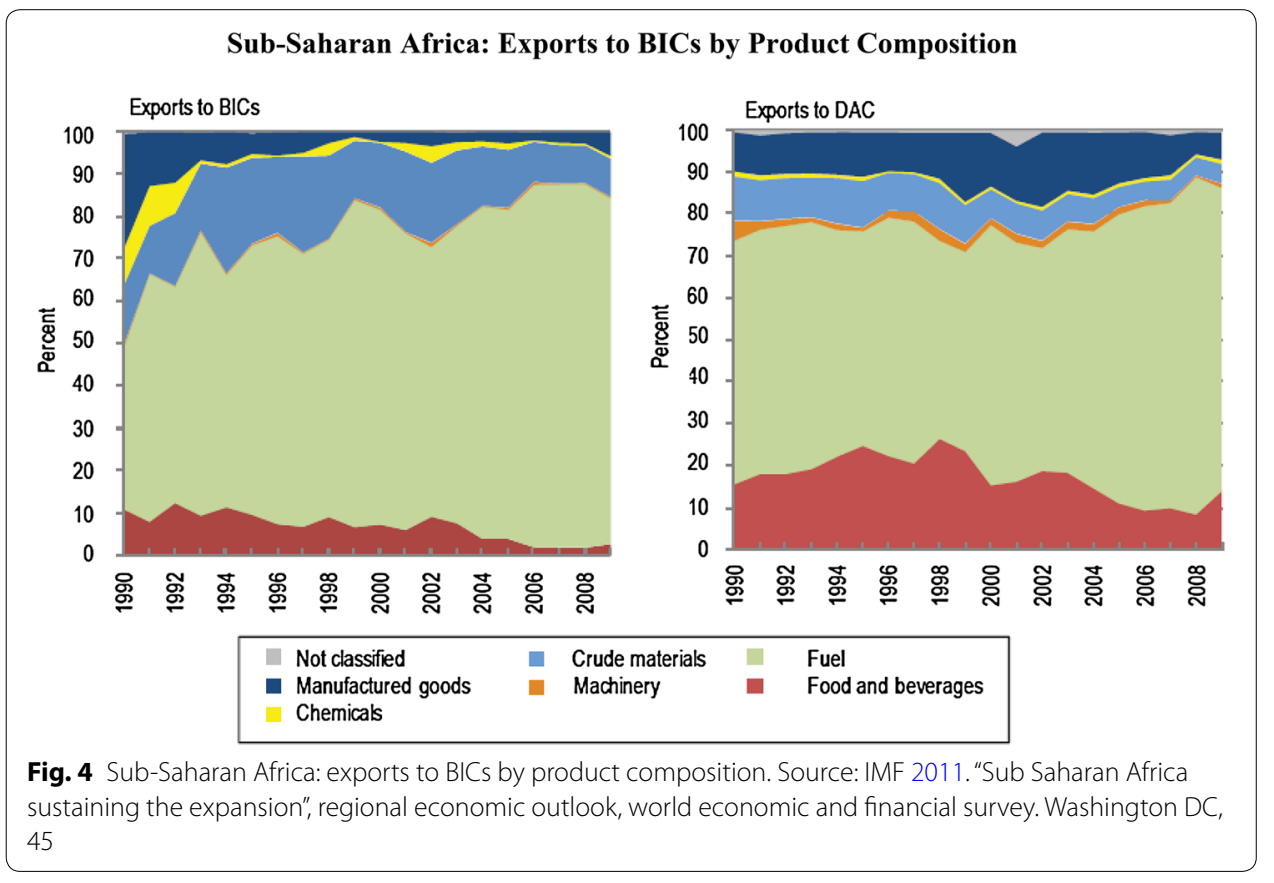

directed toward manufacturing, construction, finance, agriculture, and service (Miria Pigato and Julien Gourdon 2014:16-17) (Fig. 7).

The leading African recipient of FDI from China is South Africa, which has a stock of about $\$ 3$ billion and accounts for nearly 40 per cent of total Chinese FDI stock in the region. Other important recipients are Nigeria (with a stock of $\$ 796$ million), Zambia 


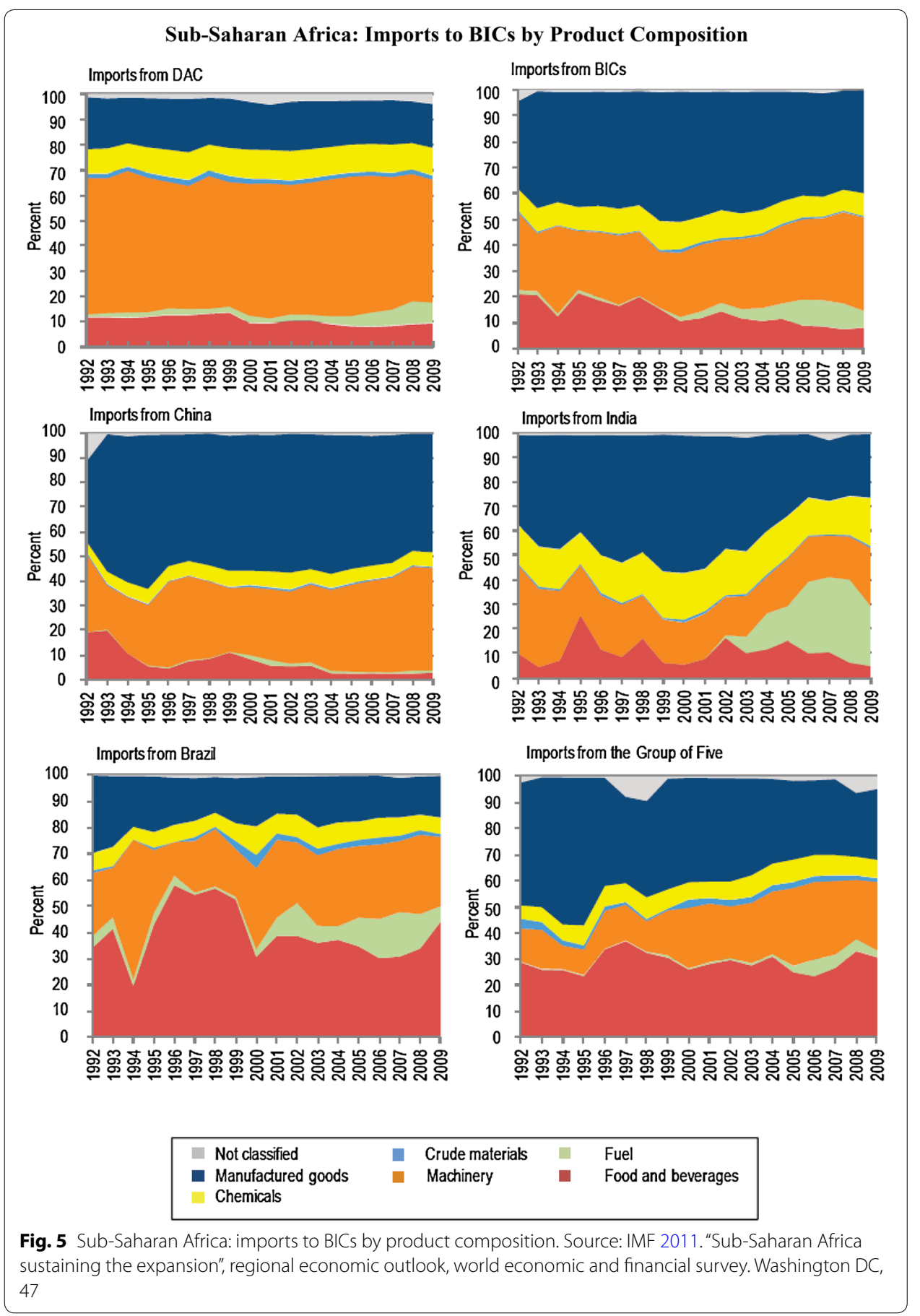

(\$651 million), Sudan (\$528 million), Algeria (\$509 million), Mauritius(\$230 million), United Republic of Tanzania (\$190 million), Madagascar (\$147 million), Niger (\$137 million), Congo (\$134 million), Egypt (\$131 million) and Ethiopia (\$127 million).

Historically, Indian FDI in Africa was concentrated in Mauritius. During the period 1996-2005, accumulated flows to the country reached \$1.4 billion, accounting for $9 \%$ of total outward FDI from India. More recently, large Indian investment projects have been implemented in other countries, such as Côte d'Ivoire, Senegal and Sudan. 

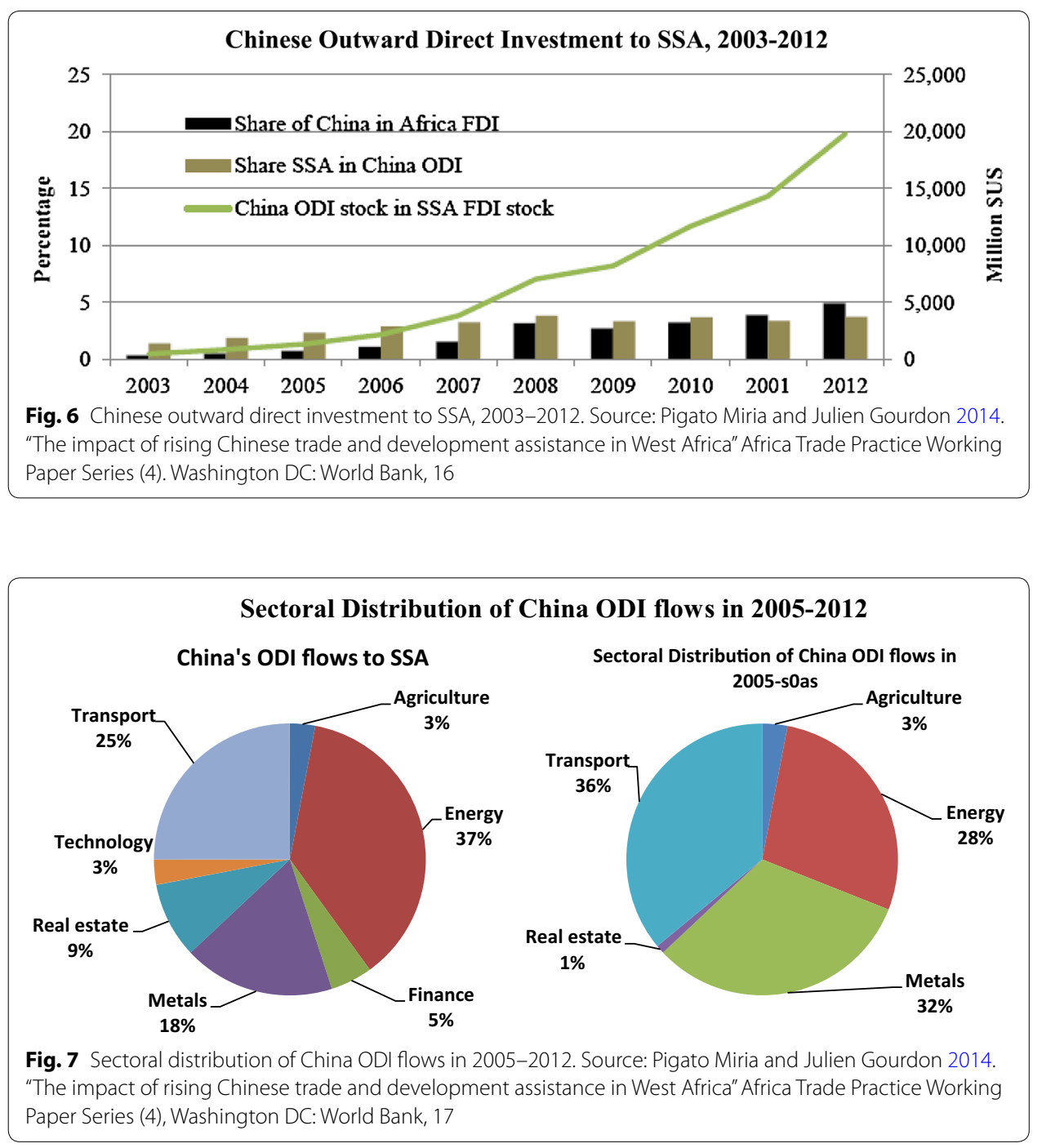

Within Latin America and the Caribbean, Brazil is the most important investor in Africa. For instance, Brazilian energy giant Petrobr as has operations in Angola, Libyan Arab Jamahiriya, Mozambique, Nigeria, Senegal and the United Republic of Tanzania, whereas mining company Vale is present in Angola, the Democratic Republic of Congo, Gabon, Ghana, Mozambique, South Africa and Zambia. Other examples of Brazilian investors active in Africa are bus maker Marcopolo, which has a plant in South Africa, and conglomerate Odebrecht, which primarily has engineering and construction projects in Angola, Djibouti, Liberia, Libyan Arab Jamahiriya and Mozambique (UNCTAD 2010:84-88).

\section{3-Development assistance}

According to UNCTAD: Official development assistance (ODA) refers to grants or loans to developing countries that: (a) are undertaken by the official sector; (b) have the promotion of economic development and welfare as the main objective; (c) are at concessional financial terms, having a grant element of at least $25 \%$ (UNCTAD 2010:49). 
The contribution of the BICs to development assistance has increased over the last decade, with China leading the way. Aid from the BICs (particularly China) promotes their trade and investment, but the BICs continue to support Africa's development through project aid-aimed at improving infrastructure-concessionary and soft loans, as well as credits and grants. Official flows from the BICs often go to African countries not targeted by traditional partners, with concessional loans as China's main instrument of support (ECA 2013:16) (Fig. 8).

Figure 8 shows the relative importance of Chinese ODI and ODA in SSA as a whole. The 2009 data are outliers because they include a US $\$ 3$ billion loan to Ghana, which represents about $75 \%$ of total ODA for West Africa. And in 2010 Mauritania accounted for $50 \%$ of China's ODA to West Africa (having received a US \$1.3 million loan from China). Aside from Ghana and Mauritania, however, the other countries in the region receive a relatively small amount of ODA. Chinese assistance is widely distributed among different sectors; includes loans and grants for energy, infrastructure, water supply, sanitation, health, education projects, as well as investments in sports stadiums and cultural centers (Miria Pigato and Julien Gourdon 2014:18).

China is the main source of Southern aid to Africa, at 83 per cent of Southern (nonDAC) flows in 2006, or $\$ 2.3$ billion, while Brazil pledged an estimated \$96.1 million and India $\$ 11.3$ million that year. The Aid data initiative has reported recent official flows from Brazil to selected African countries of around \$2.9 million (2009); \$15.2 million from India (2010); and \$60.1 million from South Africa (2008). The OECD estimates Russia to have disbursed \$33.1 million in 2011.

Key features of BICs aid to Africa (particularly China, and to some extent India and Brazil) is use of official flows to promote trade and investment. China's aid to Africa is driven largely by its objective of securing access to oil and minerals, and nearly $70 \%$ of its infrastructure financing in Africa is concentrated in Angola, Ethiopia, Nigeria and Sudan, all of which have oilfields. Angola, Democratic Republic of Congo and Sudan have major oilfields and pay for much of their assistance or loans from China with oil. Sudan sends $60 \%$ of its crude oil to China.

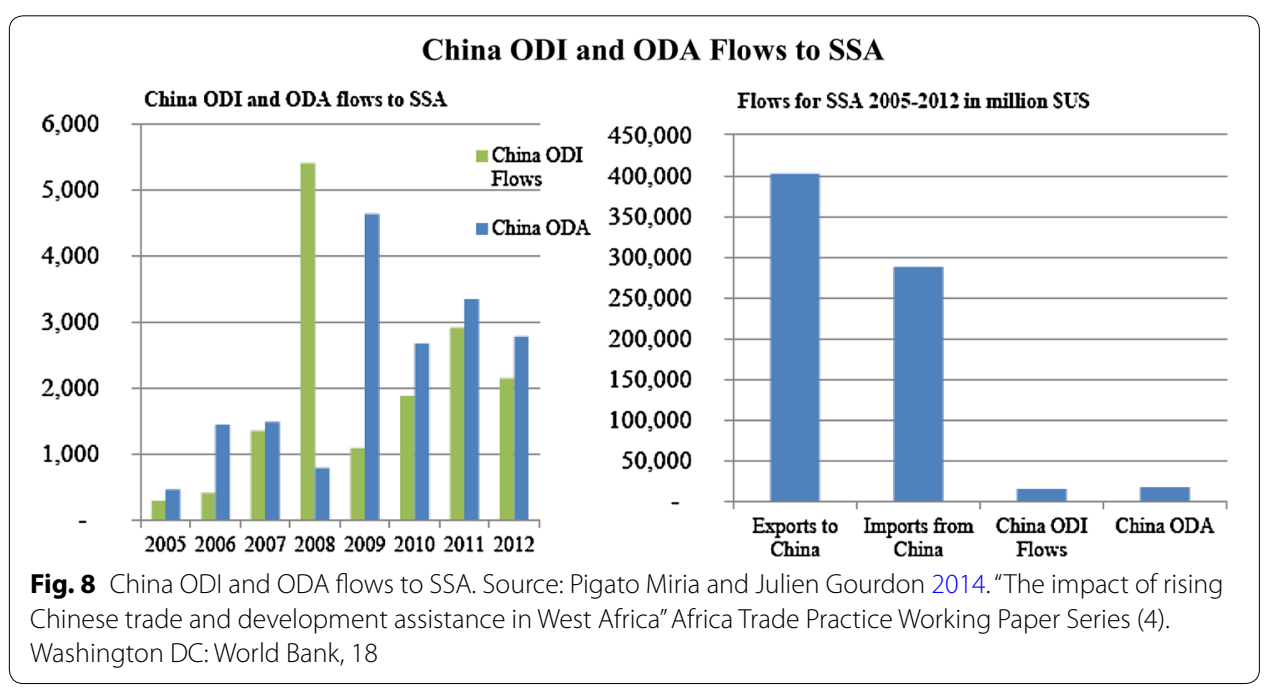


Another key feature of Southern partners' support is that official flows target African countries seldom reached by traditional partners. The support is increasingly provided to countries such as Angola, Sudan and Zimbabwe, while India is known to have provided support to Angola, Côte d'Ivoire, Djibouti and Niger. Concessional loans are the most widespread instrument of BICs support to African countries. Over 2001-2007, half of China's infrastructure finance to African economies outside North Africa was in the form of loans.

Technical cooperation is a key part of BICs countries' support to Africa (particularly from Brazil and India). In 2008 for example, Brazil provided technical assistance through the Brazilian Technical Cooperation Agency, of which $43 \%$ of resources for training went to Africa (Angola, Cape Verde, Guinea-Bissau, Mozambique and São Tomé and Príncipe-have been the main beneficiaries, accounting for $74 \%$ of Brazil's technical cooperation to Africa). India, for its part, provides technical assistance through the Indian Technical and Economic Cooperation programme, focusing on improving services in education, health and ICT (EAC 2013:17-18).

\section{4-Economic impact of Sub-Saharan Africa's engagement with new partners}

First, Sub-Saharan Africa's trade reorientation is the result of an increase in its trade with emerging partners, not trade diversion, and therefore the region experiences the benefits commonly associated with any expansion in international trade. Second, trading with a larger number of partners appears to be reducing the region's historically high export volatility, which could foster its long-term economic growth. Third, emerging partners' financing of Sub-Saharan Africa's economic activities can help boost economic growth. Fourth, growth of emerging partners has an indirect economic benefit for Sub-Saharan Africa because it has strengthened commodity prices, thus improving the terms of SubSaharan Africa's trade with traditional and nontraditional partners (Dieri-Wake Nabine 2009:21-22).

Fifth the increase in trade prompted by emerging partners fosters specialization along comparative advantages, thereby boosting productivity and output. By increasing economies of scale, trade with emerging partners lowers Sub-Saharan Africa's costs of production and increases the variety of goods available, which is particularly important for most small Sub-Saharan African countries with small middle classes. Sub-Saharan Africa's exports to new partners also benefit the region dynamically through technological transfer and the related learning by doing impact on economic growth (Marteus Brackner and Daniel Lederman 2012:20).

Sixth the economic impact of FDI from emerging partners on Sub-Saharan African countries goes beyond higher foreign exchange reserves and potentially higher tax revenues. FDI in manufacturing (for example, in Ghana, Mauritius, and Nigeria, among others), agriculture (including food processing), and tourism fosters productivity growth in the region through technology transfer.

Also important are investments in financial services, because financial development is linked to higher long-term growth.

Seventh most important, emerging partners' financing of infrastructure (which is often associated with large-scale FDI), mainly from China, is particularly effective in 
improving competitiveness in such an infrastructure deprived region as Sub-Saharan Africa (IMF 2011:52-57).

\section{Opportunities, challenges and policy implications 1-Opportunities}

Engagement with emerging partners raises opportunities for sub-Saharan African countries as follows:

- Outsourcing of economic activities to Sub-Saharan Africa. Rising wages in Brazil, China, India, and other countries could prompt them to further outsource their economic activities to Sub-Saharan Africa, especially in light manufacturing. The BICs are increasingly moving up the value chain (for instance, China and India in manufacturing, and Brazilin biofuels) with the potential to outsource these activities to Sub-Saharan Africa. Globalre balancing between advanced and emerging economies could accelerate this process, with more rapid industry upgrading in China and India.

- Low-cost inputs and consumption goods. Sub-Saharan Africa stands to benefit from imports available at a much lower cost from emerging partners than from traditional partners. Low-cost capital goods boost the productivity of Sub-Saharan Africa's producers, whereas low-cost manufactured imports benefit consumers and producers (through lower wage pressures and cheaper inputs).

- Access to more appropriate technologies. Through intensifying trade and investment relationships with other developing countries, countries in the region also have access to cheaper and less-sophisticated technologies that may be more appropriate for their level of development.

- Economic benefits from intraregional integration. Intraregional integration could also boost growth by promoting horizontal FDI, creating economies of scale and improving the allocation of factors of production within the region (Stephen N. Karingi and Unicent Leyaro 2009:35).

\section{2-Challenges}

The increasing engagement with emerging partners also poses a number of challenges:

- Natural resource curse. Because the region's trade relationship with larger emerging partners is overwhelmingly concentrated on exports of raw commodities, inadequate management of natural resource wealth could lead to many of the economic problems commonly associated with natural resource dependence. Sub-Saharan African countries have experienced these problems for decades: crowding out of highervalue-added activities, pro cyclical macroeconomic policy, an unsustainably rapid depletion of resources, and high volatility in terms of trade.

- Transitional costs. Increasing trade with new partners has resulted in a reallocation of factors of production and consequent transitional costs, such as failing businesses and higher unemployment. For instance, non-commodity sectors such as manufacturing or food processing can be negatively affected by lower cost imports from other countries (for example, manufactured products from China or processed food from Brazil) and from currency appreciation resulting from higher commodity exports. 
- Rapid structural changes. The growing engagement of Sub-Saharan African countries with emerging partners and their ongoing economic rise will most likely continue to bring substantial changes to the supply of and demand for Sub-Saharan African products. High economic growth in emerging economies may further boost commodity prices, and higher wages in manufacturing and services in emerging partners may prompt them to outsource some of their activities to Sub-Saharan Africa. At the same time, new technologies may affect the integration of production processes between Sub-Saharan Africa and emerging partners. Such changes may be as strong and far-reaching as the recent commodity prices boom and could prove very hard for Sub-Saharan Africa entrepreneurs and governments to anticipate (IMF 2011:59-60).

\section{3-Policy implications}

\section{Recommendations for African countries}

a. Main stream South-South cooperation into national development strategies. African countries should adopt a well-defined strategy for South-South cooperation to ensure that it furthers rather than hinders the achievement of national and regional development goals.

b. Take a proactive approach to the partnership process. The scale and scope of interaction between African countries and developing countries partners has expanded rapidly in the last 15 years. A proactive approach by African governments and sharing of experiences with developing country partners will accelerate mutual policy learning, which should enhance the effectiveness of interactions for both parties.

c. Ensure that cooperation with developing countries complements existing partnerships with developed countries.

d. Involve more local stakeholders in partnerships with the South. To ensure effective national ownership of the process and outcomes of the evolving partnerships between Africa and developing countries, African governments should make efforts to get parliaments, the private sector and civil society more involved in the process.

e. Strengthen efforts to develop productive capacities. This requires public and private investment, structural transformation and the development of productive capacities. The current pattern of trade with developing countries is reinforcing commodity dependence and replicating the existing pattern of trade with traditional partners. African countries should reverse this export pattern and transform the structure of their economies. This requires improving the business environment, addressing the problem of poor infrastructure, enhancing access to credit and transfer of skills and technology (David Dollar 2008:5-7).

f. Enhance capacity to negotiate and benefit from the multilateral trading system.

g. Play a more active role in coordination of support from partners. To reduce transaction costs and increase the development impact. In this regard, there is a need to develop or strengthen existing national aid management and coordination frameworks to enhance local ownership of aid processes and outcomes (Ali Zafar 2010:14-17).

h. Avoid accumulation of unsustainable debt. African countries should ensure that new borrowing from developing country partners is used to finance projects that enhance domestic capacity to repay. There is also the need to pay more attention to the structure as well as management of external debt to avoid a debt crisis. 
i. Adopt a developmental approach in seeking foreign direct investment. African countries should recognize that ultimately the most effective way to attract FDI is to have a dynamic and growing domestic private sector. If they wish to attract market-seeking or efficiency-seeking FDI, instead of resource-seeking FDI,they have to create a growing and efficient domestic market coupled with a policy environment attractive to both domestic and foreign investors. In this regard, the focus of African countries should not be on attracting Southern FDI per se, rather it should be on creating linkages between FDI and the domestic economy and also directing it to sectors where it can catalyze domestic investment, create employment, spur regional integration and boost productive capacity (UNCTAD 2014:87) (UNCTAD 2010:102-104).

\section{Recommendations for developing country partners}

a. Broaden the scope of engagement to include sectors other than the extractive industries.

b. Strengthen support for regional integration in Africa.

c. Enlarge country coverage.

d. Provide more information on development activities in the region.

e. Ensure that projects have positive impact on the environment.

f. Address the transactions costs associated with the multiplicity of partnership initiatives (Corinne Delechat 2009:27).

\section{Recommendations for developed country partners}

a. Provide more support for Africa-South cooperation.

b. Strengthen dialogue with Southern partners (UNCTAD 2009: 95).

\section{Recommendations for regional and multilateral institutions}

a. Coordinate the development of statistics and collection of information on AfricaSouth cooperation.

b. Provide more research support.

c. Establish financing facilities for Africa-South cooperation (UNCTAD 2010:105108).

\section{Conclusion}

Trade between the BICs and Africa can be summarized under three key features: Africa's exports to the BICs are dominated by fuels and primary commodities (mainly to China and India); the BIC's exports to African countries are dominated by manufactured goods; and although some African countries will gain, some will lose.

Chinese FDI can be categorized as resource-efficiency-and market-seeking investments. The policy upshot of the first type is that African economies need to invest their gains from primary commodity exports in downstream, higher value added industries, which should allow the continent's natural-resource exporters to develop and diversify their export base, so moving from dependence on natural resource exports. 
The equivalent policy implication for China's efficiency-seeking investments is that African governments should help such investors to forge linkages with local African domestic producers, thereby producing sustainable exports for African economies with higher domestic value added, which should strengthen domestic businesses. The policy challenge for African governments with market-seeking investments is to ensure that domestic suppliers perform acceptably on price, delivery and service quality.

African governments should also enhance the benefits of market- or efficiency-seeking Chinese FDI by ensuring the outsourcing of their activities to local entrepreneurs; increasing local sourcing of inputs for production; and ensuring the employment of local workers under fair labour practices.

Official flows from the BICs are a small portion of ODA to Africa; some of the aid from the BICs (particularly China) promotes trade and investment; ODA from the BICs often benefits African countries not targeted by traditional partners; concessional loans are China's main instrument; and technical cooperation is crucial in education, health and ICT, particularly from Brazil and India.

Competing interests

The author declares that she has no competing interests.

\section{Appendix}

\section{Gravity model variables}

\begin{tabular}{llllllllll}
\hline $\mathbf{y}$ & $\mathbf{X 1}$ & $\mathbf{X} \mathbf{1}$ & $\mathbf{X 3}$ & $\mathbf{X 4}$ & $\mathbf{X 5}$ & $\mathbf{X 6}$ & $\mathbf{X 7}$ & $\mathbf{X 8}$ & $\mathbf{X 9}$ \\
\hline 4.50 & $99,214.60$ & 107.60 & $127,643.00$ & 167.98 & 2.20 & 1.00 & 61.00 & 15.90 & 1.00 \\
4.80 & $107,449.70$ & 107.50 & $127,627.00$ & 169.80 & 2.71 & 1.00 & 63.00 & 14.70 & 1.00 \\
5.40 & $117,208.30$ & 108.40 & $128,453.00$ & 176.52 & 7.76 & 1.00 & 65.00 & 12.50 & 1.00 \\
8.40 & $128,958.90$ & 109.30 & $129,227.00$ & 180.98 & 12.20 & 1.00 & 68.00 & 10.60 & 1.00 \\
16.60 & $141,964.50$ & 109.40 & $129,988.00$ & 187.07 & 17.14 & 1.00 & 152.00 & 9.80 & 1.00 \\
21.10 & $158,020.70$ & 110.70 & $130,756.00$ & 334.52 & 20.63 & 1.00 & 201.00 & 9.20 & 1.00 \\
28.80 & $208,381.00$ & 112.00 & $131,448.00$ & 345.70 & 22.64 & 1.00 & 362.00 & 9.10 & 1.00 \\
36.40 & $237,892.80$ & 113.60 & $132,129.00$ & 385.37 & 22.76 & 1.00 & 1297.00 & 9.20 & 1.00 \\
56.00 & $260,812.00$ & 109.10 & $132,802.00$ & 373.02 & 20.98 & 1.00 & 5480.00 & 8.90 & 1.00 \\
43.30 & $28,484,408.00$ & 108.70 & $133,450.00$ & 386.08 & 20.40 & 1.00 & 1233.00 & 8.90 & 1.00 \\
67.10 & $314,602.50$ & 109.90 & $134,091.00$ & 400.82 & 19.45 & 1.00 & 1350.00 & 8.90 & 1.00 \\
93.20 & $438,853.00$ & 108.80 & $134,735.00$ & 410.64 & 18.41 & 1.00 & 2300.00 & 8.90 & 1.00 \\
102.50 & $472,436.50$ & 107.10 & $135,404.00$ & 423.75 & 17.40 & 1.00 & 3200.00 & 8.90 & 1.00 \\
19.70 & $503,217.90$ & 107.10 & $136,072.00$ & 435.62 & 16.41 & 1.00 & 4500.00 & 8.90 & 1.00 \\
\hline
\end{tabular}

\section{Regression} Notes

Output created

07-May-2015 19:03:23

Comments

Input

$\begin{array}{ll}\text { Data } & \text { DataSet 1 } \\ \text { Active dataset } & <\text { none> } \\ \text { Filter } & <\text { none> } \\ \text { Weight } & <\text { none> } \\ \text { Split file } & 14 \\ \text { N of rows in working Data file } & \end{array}$




\begin{tabular}{ll}
\hline Missing value handling & User-defined missing values are \\
& treated as missing. \\
Cases used & Statistics are based on cases with \\
& no missing values for any variable \\
& used. \\
Syntax & REGRESSION \\
& /DESCRIPTIVES MEAN STDDEV CORR \\
& SIG N \\
& /MISSING LISTWISE \\
& /STATISTICS COEFF OUTS BCOV R \\
& ANOVA COLLIN TOL CHANGE ZPP \\
& /CRITERIA $=$ PIN (.05) POUT(.10) \\
& /NOORIGIN \\
& /DEPENDENT y \\
& /METHOD $=$ ENTER $\times 1 \times 2 \times 3 \times 4 \times 5 \times 6$ \\
& $\times 7 \times 8 \times 9$ \\
& /RESIDUALS DURBIN \\
& $00: 00: 00.02$ \\
Resources & $00: 00: 00.02$ \\
Elocessor time & 8272 bytes \\
Elapsed time & 0 bytes \\
Memory required & \\
Additional memory required for & \\
residual plots & \\
&
\end{tabular}

\section{Warnings}

For models with dependent variable y, the following variables are constants or have missing correlations: $\mathrm{x} 6, \mathrm{x} 9$. They will be deleted from the analysis.

\section{Descriptive statistics}

\begin{tabular}{llll}
\hline & Mean & Std. Deviation & N \\
\hline$y$ & 36.2714 & $32.45,521$ & 14 \\
x1 & $2,262,387.1714$ & $7,548,493.84,088$ & 14 \\
x2 & 109.2286 & 1.86689 & 14 \\
x4 & $131,701.7857$ & 2853.01334 & 14 \\
x5 & 312.7050 & 108.73762 & 14 \\
x6 & 15.7921 & 6.93553 & 14 \\
x7 & 1.0000 & .00000 & 14 \\
x8 & 1452.2857 & 1787.10365 & 14 \\
x9 & 10.3143 & 2.34549 & 14 \\
\hline
\end{tabular}

\section{Correlations}

\begin{tabular}{|c|c|c|c|c|c|c|c|c|c|c|}
\hline & $y$ & $x 1$ & $x 2$ & x3 & $x 4$ & $\times 5$ & $x 6$ & $x 7$ & $x 8$ & x9 \\
\hline \multicolumn{11}{|c|}{ Pearson correlation } \\
\hline y & 1.000 & .076 & -.040 & .772 & .745 & .524 & - & .544 & -.593 & - \\
\hline$x 1$ & .076 & 1.000 & -.086 & .194 & .210 & .200 & - & -.022 & -.185 & - \\
\hline$x 2$ & -.040 & -.086 & 1.000 & -.033 & .181 & .603 & - & -.256 & -.383 & - \\
\hline$\times 3$ & .772 & .194 & -.033 & 1.000 & .944 & .688 & - & .740 & -.801 & - \\
\hline$x 4$ & .745 & .210 & .181 & .944 & 1.000 & .771 & - & .685 & -.795 & - \\
\hline$\times 5$ & .524 & .200 & .603 & .688 & .771 & 1.000 & - & .393 & -.945 & - \\
\hline$x 6$ & - & - & - & - & - & - & 1.000 & - & - & - \\
\hline$x 7$ & .544 & -.022 & -.256 & .740 & .685 & .393 & - & 1.000 & -.495 & - \\
\hline
\end{tabular}




\begin{tabular}{lllllllllll}
\hline & $\mathbf{y}$ & $\mathbf{x 1}$ & $\mathbf{x 2}$ & $\mathbf{x 3}$ & $\mathbf{x 4}$ & $\mathbf{x} 5$ & $\mathbf{x 6}$ & $\mathbf{x 7}$ & $\mathbf{x 8}$ & $\mathbf{x 9}$ \\
\hline x8 & -.593 & -.185 & -.383 & -.801 & -.795 & -.945 & - & -.495 & 1.000 & - \\
x9 & - & - & - & - & - & - & - & - & - & 1.000 \\
Sig. (1-tailed) & & & & & & & & & \\
y & & .398 & .446 & .001 & .001 & .027 & .000 & .022 & .013 & .000 \\
x1 & .398 & - & .385 & .253 & .236 & .247 & .000 & .471 & .263 & .000 \\
x2 & .446 & .385 & - & .455 & .268 & .011 & .000 & .189 & .088 & .000 \\
x3 & .001 & .253 & .455 & - & .000 & .003 & .000 & .001 & .000 & .000 \\
x4 & .001 & .236 & .268 & .000 & - & .001 & .000 & .003 & .000 & .000 \\
x5 & .027 & .247 & .011 & .003 & .001 & - & .000 & .082 & .000 & .000 \\
x6 & .000 & .000 & .000 & .000 & .000 & .000 & - & .000 & .000 & .000 \\
x7 & .022 & .471 & .189 & .001 & .003 & .082 & .000 & - & .036 & .000 \\
x8 & .013 & .263 & .088 & .000 & .000 & .000 & .000 & .036 & - & .000 \\
x9 & .000 & .000 & .000 & .000 & .000 & .000 & .000 & .000 & .000 & - \\
$N$ & & & & & & & & & & \\
y & 14 & 14 & 14 & 14 & 14 & 14 & 14 & 14 & 14 & 14 \\
x1 & 14 & 14 & 14 & 14 & 14 & 14 & 14 & 14 & 14 & 14 \\
x2 & 14 & 14 & 14 & 14 & 14 & 14 & 14 & 14 & 14 & 14 \\
x3 & 14 & 14 & 14 & 14 & 14 & 14 & 14 & 14 & 14 & 14 \\
x4 & 14 & 14 & 14 & 14 & 14 & 14 & 14 & 14 & 14 & 14 \\
x5 & 14 & 14 & 14 & 14 & 14 & 14 & 14 & 14 & 14 & 14 \\
x6 & 14 & 14 & 14 & 14 & 14 & 14 & 14 & 14 & 14 & 14 \\
x7 & 14 & 14 & 14 & 14 & 14 & 14 & 14 & 14 & 14 & 14 \\
x8 & 14 & 14 & 14 & 14 & 14 & 14 & 14 & 14 & 14 & 14 \\
x9 & 14 & 14 & 14 & 14 & 14 & 14 & 14 & 14 & 14 & 14 \\
\hline & & & & & & & & & & \\
\hline
\end{tabular}

\section{Variables entered/removed}

\begin{tabular}{llll}
\hline Model & Variables entered & Variables removed & Method \\
\hline 1 & $\times 8, \times 1, \times 2, \times 7, \times 4, \times 3, \times 5^{\mathrm{a}}$ & - & Enter \\
\hline
\end{tabular}

Dependent variable: $y$

a All requested variables entered.

Model summary

\begin{tabular}{|c|c|c|c|c|c|c|c|c|c|c|}
\hline \multirow[t]{2}{*}{ Model } & \multirow[t]{2}{*}{$\mathbf{R}$} & \multirow[t]{2}{*}{ R square } & \multirow{2}{*}{$\begin{array}{l}\text { Adjusted R } \\
\text { square }\end{array}$} & \multirow{2}{*}{$\begin{array}{l}\text { Std. error } \\
\text { of the } \\
\text { estimate }\end{array}$} & \multicolumn{5}{|c|}{ Change statistics } & \multirow{2}{*}{$\begin{array}{l}\text { Durbin- } \\
\text { Watson }\end{array}$} \\
\hline & & & & & $\begin{array}{l}\text { R square } \\
\text { change }\end{array}$ & F change & df1 & df2 & $\begin{array}{l}\text { Sig. F } \\
\text { change }\end{array}$ & \\
\hline 1 & $.801^{\mathrm{a}}$ & .641 & .222 & 28.62158 & .641 & 1.531 & 7 & 6 & .310 & 1.512 \\
\hline
\end{tabular}

a Predictors: (constant), x8, x1, x2, x7, x4, x3, x5

Dependent variable: $y$

\section{ANOVA}

\begin{tabular}{lllllll}
\hline Model & & Sum of squares & df & Mean square & F & Sig. \\
\hline 1 & Regression & 8778.258 & 7 & 1254.037 & 1.531 & $.310^{\mathrm{a}}$ \\
& Residual & 4915.170 & 6 & 819.195 & \\
& Total & $13,693.429$ & 13 & & \\
\hline
\end{tabular}

Dependent variable: $y$

a Predictors: (constant), x8, x1, x2, x7, x4, x3, x5 


\section{Coefficients}

\begin{tabular}{|c|c|c|c|c|c|c|c|c|c|c|c|}
\hline \multirow{2}{*}{\multicolumn{2}{|c|}{ Model }} & \multicolumn{2}{|c|}{$\begin{array}{l}\text { Unstandardized } \\
\text { coefficients }\end{array}$} & \multirow{2}{*}{$\begin{array}{l}\text { Stand- } \\
\text { ardized } \\
\text { coeffi- } \\
\text { cients } \\
\text { Beta }\end{array}$} & & \multirow[t]{2}{*}{ Sig. } & \multicolumn{3}{|c|}{ Correlations } & \multicolumn{2}{|c|}{$\begin{array}{l}\text { Collinearity } \\
\text { statistics }\end{array}$} \\
\hline & & B & $\begin{array}{l}\text { Std. } \\
\text { error }\end{array}$ & & & & $\begin{array}{l}\text { Zero- } \\
\text { order }\end{array}$ & Partial & Part & $\begin{array}{l}\text { Toler- } \\
\text { ance }\end{array}$ & VIF \\
\hline \multirow[t]{8}{*}{1} & (Constant) & -143.836 & 3033.684 & & -.047 & .964 & & & & & \\
\hline & $x 1$ & $-9.234 \mathrm{E}-007$ & .000 & -.215 & -.693 & .514 & .076 & -.272 & -.169 & .622 & 1.607 \\
\hline & $\times 2$ & -8.287 & 12.471 & -.477 & -.665 & .531 & -.040 & -.262 & -.163 & .116 & 8.601 \\
\hline & $\times 3$ & .007 & .017 & .606 & .399 & .704 & .772 & .161 & .098 & .026 & 38.491 \\
\hline & $x 4$ & .084 & .395 & .280 & .212 & .839 & .745 & .086 & .052 & .034 & 29.287 \\
\hline & $\times 5$ & 4.380 & 8.049 & .936 & .544 & .606 & .524 & .217 & .133 & .020 & 49.459 \\
\hline & $x 7$ & .005 & .008 & .272 & .598 & .572 & .544 & -.237 & -.146 & .289 & 3.462 \\
\hline & x8 & 8.893 & 20.876 & .643 & .426 & .685 & -.593 & .171 & .104 & .026 & 38.048 \\
\hline
\end{tabular}

Dependent variable: $\mathrm{y}$

\section{Coefficient correlations}

\begin{tabular}{lllllllll}
\hline Model & & $\mathbf{x 8}$ & $\mathbf{x 1}$ & $\mathbf{x 2}$ & $\mathbf{x 7}$ & $\mathbf{x 4}$ & $\mathbf{x 3}$ & $\mathbf{x 5}$ \\
\hline $1 \quad$ Correlations & $\times 8$ & 1.000 & -.226 & -.290 & -.187 & -.588 & .626 & .899 \\
& $\times 1$ & -226 & 1.000 & .550 & .461 & -.143 & .109 & -.391 \\
& $\times 2$ & -.290 & .550 & 1.000 & .527 & -.289 & .363 & -.616 \\
& $\times 7$ & -.187 & .461 & .527 & 1.000 & -.174 & .000 & -.305 \\
& $\times 4$ & -.588 & -.143 & -.289 & -.174 & 1.000 & -.919 & -.428 \\
& $\times 3$ & .626 & .109 & .363 & .000 & -.919 & 1.000 & .362 \\
& $\times 5$ & .899 & -.391 & -.616 & -.305 & -.428 & .362 & 1.000 \\
Covariances & $\times 8$ & 435.821 & $-6.287 \mathrm{E}-006$ & -75.503 & -.032 & -4.852 & .226 & 151.009 \\
& $\times 1$ & $-6.287 \mathrm{E}-006$ & $1.877 \mathrm{E}-012$ & $9.140 \mathrm{E}-006$ & $5.083 \mathrm{E}-009$ & $-7.509 \mathrm{E}-0082.504 \mathrm{E}-009-4.194 \mathrm{E}-006$ \\
& $\times 2$ & -75.503 & $9.140 \mathrm{E}-006$ & 155.515 & .054 & -1.422 & .078 & -61.804 \\
& $\times 7$ & -.032 & $5.083 \mathrm{E}-009$ & .054 & $6.831 \mathrm{E}-005$ & -.001 & $2.462 \mathrm{E}-008-.020$ \\
& $\times 4$ & -4.852 & $-7.509 \mathrm{E}-008$ & -1.422 & -.001 & .156 & -.006 & -1.361 \\
& $\times 3$ & .226 & $2.504 \mathrm{E}-009$ & .078 & $2.462 \mathrm{E}-008-.006$ & .000 & .050 \\
& $\times 5$ & 151.009 & $-4.194 \mathrm{E}-006$ & -61.804 & -.020 & -1.361 & .050 & 64.793
\end{tabular}

Dependent variable: $\mathrm{y}$

\section{Collinearity diagnostics}

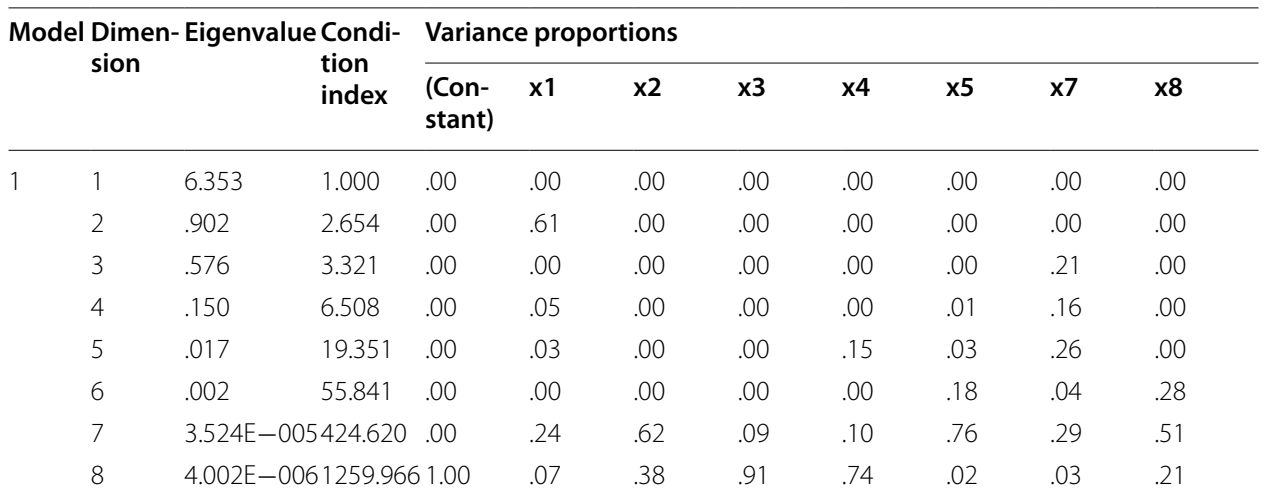

Dependent variable: y 
Residuals Statistics

\begin{tabular}{lccccc}
\hline & Minimum & Maximum & Mean & Std. Deviation & N \\
\hline Predicted value & 1.1063 & 76.2000 & 36.2714 & 25.98559 & 14 \\
Residual & -51.30946 & 27.89357 & .00000 & 19.44454 & 14 \\
$\begin{array}{l}\text { Std. predicted } \\
\quad \text { value }\end{array}$ & -1.353 & 1.537 & .000 & 1.000 & 14 \\
Std. residual & -1.793 & .975 & .000 & .679 & 14 \\
\hline
\end{tabular}

\section{Dependent variable: $\mathrm{y}$}

Received: 4 September 2015 Accepted: 27 May 2016

Published online: 03 October 2016

\section{References}

Bruckner, Markus, and Daniel Lederman. 2012. Trade growth in Sub-Saharan Africa, policy research working paper (6007) Washington DC: World Bank.

Delechat, Corinne, et al. 2009. Sub-Saharan Africa integration in the global financial markets IMF working paper (WP/09/114). Washington DC: IMF.

Dollar, David. 2008. Lessons for Africa policy research working paper. Washington DC: World Bank.

Economic Commission for Africa (ECA). 2013. Africa-BRICS cooperation: implications for growth, employment, and structural transformation in Africa, Addis Ababa.

Economic Commission for Africa(ECA). 2010. Enhancing intra-African Trade, Assessing Regional Integration in Africa IV. Addis Ababa: ECA.

Foster Vivien. 2009. Building bridges China's growing role as infrastructure financier for Sub-Saharan Africa, public private infrastructure advisory facility (PPIAF), trends and policy options (5) Washington DC: World Bank.

Harry, Baoadman G. 2007. Africa's silk road China and economic frontier. Washington DC: World Bank.

IMF. 2011. Sub-Saharan Africa sustaining the expansion, regional economic outlook, world economic and financial survey, Washington DC.

Karingi N. Stephen, and Vincent Leyaro. 2009. Monitoring aid for trade in Africa an assessment of the effective ness of the aid for trade, African Trade Policy Centre (ATPC), Work in Progress (83), Addis Ababa, ECA.

Nabine Wake-Djeri. 2009. The Impact of Chinese investment and trade on Nigeria economic growth, African Trade Policy Centre (ATPC), Work in Progress (771). Addis Ababa: ECA.

Pigato Miria, and Julien Gourdon. 2014. "The Impact of Rising Chinese Trade and Development Assistance in West Africa" Africa Trade Practice Working Paper Series (4), Washington DC: World Bank.

Qimiao, Fan, et al. 2007. The investment climate in Brazil, India and South Africa, a comparison of approaches for sustaining economic growth in emerging economies, WBl learning resource series (42533). World Bank: Washington DC.

Subramanian Uma, and Matthias Matthijs. 2007. Can Sub-Saharan Africa leap into global net work trade? World Bank Policy Research Working Paper (4112), Washington DC.

UNCTAD. 2010. South-South cooperation: Africa and new forms of development partner ship, Economic Development of Africa Report. New York.

UNCTAD. 2005. Rethinking the role of foreign direct investment, Economic development in Africa report. New York.

UNCTAD. 2009. Strengthening regional economic integration for Africa's development, Economic Development in Africa report. New York.

UNCTAD. 2014. Catalyzing investment for transformative growth in Africa, Economic development report in Africa. New York.

UNCTAD. 2005. South-South cooperation in international investment arrangements, UNCTAD Series on international investment policies for development. New York.

UNCTAD. 2008. South-South cooperation and regional integration: where we stand and future direction, Investment enterprise and development commission. New York.

Viven, Foster, et al. 2008. Chinese emerging role in Africa: part of the changing land scape of infrastructure finance, public private infrastructure advisory facility (PPIAF). Washington DC: World Bank.

Zafar, A. 2007. The growing relationship between China and Sub Saharan Africa: macroeconomic trade, investment, and aid link. World Bank: Washington DC.

Zafar Ali. 2010. Learning from the Chinese miracle: development lessons for Sub Saharan Africa, policy research working paper (5216). Washington D.C. 